\title{
An Evaluation Of The Co-Operative Business Model Within The Context Of The Global Reporting Initiative
}

Marné du Toit, North-West University, South Africa

Pieter W. Buys, North-West University, South Africa

\begin{abstract}
Sustainability reporting, renowned as an instrument for businesses to communicate how they function more efficiently and responsibly within the social and physical environment, while simultaneously remaining profitable, has evolved in an up-and-coming trend by businesses. In addition, this leads to integrated reporting, which implies that a business' strategy, performance, risk and sustainability are inseparable from one another. The International Year of Co-operatives (2012), with the theme "Co-operative Enterprises Build a Better World", recognises that cooperatives, in their range of forms, support the fullest participation in the social and economic development of people. Co-operatives also have the remarkable opportunity to grow everywhere for the reason that modern society needs their role and initiatives.
\end{abstract}

This article considers to what extent the GRI guidelines, as a reporting framework, are feasible or applicable to co-operatives as a business model. The selected agricultural co-operative (AgriCom) is used in the form of a case study, where the GRI's Sustainability Reporting Guidelines are applied to its activities. This study found that the co-operative business model performed admirably well under these guidelines and suggests that the co-operative business model is very relevant in the modern business environment.

Keywords: Co-operative; Corporate Social Responsibility; Global Reporting Initiative; Integrated Reporting; Sustainability

\section{BACKGROUND}

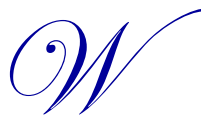

ith the recent collapse of several major businesses around the globe, accompanied by the financial scandals, the issues of sustainable development and corporate social accountability and responsibility came to light and have been on the top of many governments agendas (Jooste, 2010:98; Demiraq, 2005:11). Traditionally, the primary focus of many business owners, accountants and auditors has been on a financially focussed bottom line, concentrating typically on Net Income (NI) and/or Earnings Per Share (EPS) (Jones III \& Jonas, 2011:65). In recent times, however, there is an emerging understanding and recognition that the reason why a business is successful is not solely because of its financial performance.

The sustainable success of a business entity rather depends on its socio-ethical and environmental performances (Nikolaou, Evangelinos \& Allan, 2012:5; White, Cleveland \& White, 2008:31). It is clear that this demonstrates the shift from a single-bottom-line approach to a triple-bottom-line (TBL) approach in respect of stakeholder reporting. This approach to reporting focuses on the business entity's economic, environmental and social accomplishments (Rossouw, 2009:166; White, et al., 2008:32; Jones III \& Jonas, 2011:65). Corporate social responsibility (CSR) represents the actions a business initiates to promote some social good other than its own interests, going beyond compliance and legal obligations, and developing corporate attitudes and responsibilities in terms of society for social, environmental and ethical matters (Demiraq, 2005:11; Jones III \& Jonas, 2011:65). The GRI is recognised as the top global framework for non-financial reporting and, moreover, these guidelines are 
voluntary and provide flexibility to businesses in determining the extent of the information that should be disclosed (Levy \& Brown, 2011:129; Nikolaou et al., 2012:5).

The concepts of TBL and CSR are what co-operatives typify as an organisational model, not only in terms of its definition, but also in its underlying principles and values because a distinctive characteristic of co-operatives is that they put people at the centre of their business and not capital. It is no longer just Generally Accepted Accounting Principles (GAAP) and Generally Accepted Auditing Standards (GAAS); there are now also Corporate Social Responsibility (CSR) and Global Reporting Initiative (GRI), and with these methods come great responsibility as well as opportunities for accountants and auditors (Jones III \& Jonas, 2011:65).

The United Nations declared 2012 the International Year of Co-operatives and it proposed to elevate the public's understanding of the valuable contributions of co-operative enterprises to social integration, poverty reduction and employment creation (ICA, 2012). Furthermore, a key aim of the year is to emphasise the strengths of the co-operative business model as an alternative means of doing business and furthering socio-economic development (ICA, 2012).

\section{RESEARCH OBJECTIVE AND METHODOLOGY}

Considering the above, it is seen that the co-operative business model promotes social responsibility and other key aspects of a TBL-managed approach. The primary research question under consideration for this article can therefore be formulated as follows:

P1: To what extent could the GRI guidelines, as a social responsibility reporting framework, be feasible or applicable to co-operatives as a business model?

In answering this question, three further crucial issues need to be considered; namely, the consideration of the key components of the GRI framework, the key principles of a co-operative business model/philosophy, and the extent to which the GRI framework (current version G3.1) coincides with the objectives of the co-operative business model. The key objective of this study is therefore to determine the extent to which the GRI guidelines would be supportive of the co-operative business model. To address this objective, the article is set out as follows: Firstly, the article starts off by highlighting the evolution of sustainable development and analysing the GRI framework with the intention of discovering the key components thereof. Secondly, an evaluation of the co-operative business model and its principles is provided and, thirdly, an outline of the GRI's G3.1 Sustainability Reporting Guidelines is provided and the Indicator Protocols are assessed in terms of the objectives of the co-operative business model. In completion, the conclusions and recommendations are made together with the relevant limitations and possible future research opportunities.

In order to achieve the stated objectives, a qualitative research approach was applied along with the case study method. On the basis of underlying research epistemology, the research will also be consistent with an interpretive and critical research paradigm. The case study is based on Agri-Com Co-operative Ltd (Agri-Com), which is registered as an agricultural co-operative under South African Legislation and is currently based in the town of Bethlehem in the eastern Free State Province. The GRI guidelines are applied to the actual information and activities of this selected co-operative. Guided interviews were held with the relevant personnel of Agri-Com to obtain the necessary information in order to demonstrate in what manner a co-operative is able to perform under the GRI guidelines.

\section{SUSTAINABLE DEVELOPMENT AND THE GRI}

\subsection{Introduction}

Sustainability has become an important issue because businesses should contemplate not only on their profits, but also what they produce and how they produce it. The concept of sustainability involves the capability to sustain a high quality of life for present and future generations (Blowfield \& Murray, 2008:27). Building on sustainability, the concept of Sustainability Reporting is described by the GRI's Sustainability Reporting Guidelines 
(G3) as the practice of measuring, disclosing and being accountable to both internal and external stakeholders for organisational performance toward the goal of sustainable development (GRI, 2011a:3).

Sustainable development and CSR are two concepts with a significant purpose for governments, society and businesses within the $21^{\text {st }}$ century business environment (Munkelien, Goyer \& Fratczak, 2005:183). The evolving concept - that is CSR - continues to be a key topic in the discussions about the relationship between businesses and society and to analyse the manner in which businesses communicate such efforts (De Bakker, Ohlsson, Den Hond, Tengblad \& Turcotte, 2007:53). The correlation between the previously mentioned concepts is essential since governments are accountable for the achievement of the goals of sustainable development by signing international agreements. However, this is not possible to attain without the input and effort of the industry (Munkelien et al., 2005:183). The GRI developed the Sustainability Reporting Framework, which is generally considered as the most widely used framework for reporting business performances on human rights, labour, environmental, anti-corruption and other corporate citizenship issues (Verschoor, 2011:14; Dilling, 2010:19).

The GRI was launched in 1997 with the preliminary goal to address environmental performances, which was later broadened to include the social and economic dimensions (Jones III \& Jonas, 2011:68). The GRI Reporting Framework is intended for use by businesses of any sector, size or location since it takes into account the sensible considerations faced by a diverse range of businesses (GRI, 2011a:3). The present version, G3, was issued in 2006 and version G3.1 contains prolonged guidance on local community impacts, human rights and gender (Verschoor, 2011:14; Dilling, 2010:19). Standard disclosures set forth in the Guidelines include three aspects, which include the profile, performance indicators, and the management approach (Verschoor, 2011:14; GRI, 2011a:24). Firstly, the profile section consists of organisational strategy and analysis, its structure, report parameters, governance commitments, and engagement. Secondly, performance indicators consider the environment, human rights, labour practices and decent work environments, society, product responsibility, and economic indicators. Thirdly, the management approach section is intended to address how the organisation manages the sustainable topics associated with its risks and opportunities.

Integrated reporting is described by the King Code as a holistic and integrated representation of the business' performance in terms of both its finance and its sustainability (IoD, 2009). The main goal of the GRI is to make sustainability reporting as routine as financial reporting (Acquier \& Aggeri, 2007:151). It is clear that a business' strategy, risk, performance, and sustainability are indivisible from one another.

\subsection{The GRI's Sustainability Reporting Guidelines}

\subsubsection{Elements of the Guidelines}

It is the GRI's mission to communicate honestly and openly about sustainability since a globally shared framework of concepts, reliable language, and metrics is becoming a necessity. Furthermore, it provides a trusted and credible framework for sustainability reporting that can be used by enterprises of any sector, size or location (GRI, 2011a:2). The Guidelines are made up of Reporting Principles and Guidance and Standard Disclosures and are regarded as equal in weight and significance (GRI, 2011a:3). Application of the Principles, together with the Standard Disclosure, establishes the topics and Indicators to be reported on (GRI, 2011a:4). The Reporting Principles of materiality, sustainability, stakeholder inclusiveness, completeness, together with a set of tests for each principle, assist with the decision as to what to report on. The Standard Disclosures contain the strategy and profile section, the management approach of the organisation, and, in conclusion, the performance indicators which entail the information on the economic, environmental, and social performances of the organisation (GRI, 2011a:5).

The end result that transpires within the context of the organisation's commitments, strategy, and management approach are sustainability reports based on the GRI Reporting Framework.

\subsubsection{Application Level Criteria}

Businesses that prepare and submit GRI-based reports should state the level at which they have applied the GRI Reporting Framework via the "Application Levels" system. To meet the requirements of beginners, those in between and as well as advanced reporters, there are three levels available in the system - labelled C, B, and A. Each 
level suggests a degree of the extent of application of the GRI Reporting Framework. A plus sign at each level (e.g. $\mathrm{C}+, \mathrm{B}+, \mathrm{A}+$ ) indicates whether assurance was utilised externally for the report (GRI, 2011b:1).

The purpose of the levels is to supply the stakeholders of the business with a degree of the extent to which the GRI Guidelines have been applied in the groundwork of the report, as well as delivering preparers of the report with a clear route or vision for gradually expanding the application of the GRI Framework over time. When declaring an application level, it also clearly communicates which rudiments of the GRI Reporting Framework have been applied in the groundwork of a report (GRI, 2011b:1).

Table 1 has then also been used as the guide in evaluating the sustainability performances of Agri-Com in terms of the GRI framework

Table 1: The Levels of the GRI Sustainability Reporting Guidelines

(Adapted from GRI, 2011b)

\begin{tabular}{|c|c|c|c|c|c|c|c|}
\hline \multirow{5}{*}{ 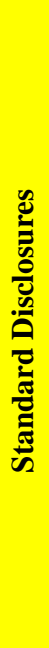 } & $\begin{array}{c}\text { Report } \\
\text { Application Level }\end{array}$ & C & $\mathrm{C}+$ & B & B+ & A & A+ \\
\hline & $\begin{array}{l}\text { Profile } \\
\text { Disclosures }\end{array}$ & $\begin{array}{c}\text { Report on: } \\
1.1 \\
2.1-2.10 \\
3.1-3.8 \\
3.10-3.12 \\
4.1-4.4 \\
4.14-4.15\end{array}$ & \multirow{4}{*}{ 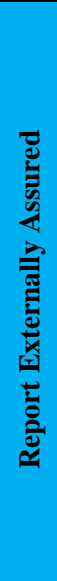 } & $\begin{array}{c}\text { Report the same as Level } \\
\text { C plus: } \\
1.2 \\
3.9,3.13 \\
4.5-4.13 \text {, } \\
4.16-4.17\end{array}$ & \multirow{4}{*}{ 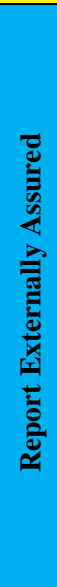 } & $\begin{array}{c}\text { Report the same as } \\
\text { Level B }\end{array}$ & \multirow{4}{*}{ 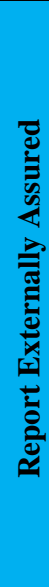 } \\
\hline & $\begin{array}{l}\text { Disclosures On } \\
\text { Management }\end{array}$ & Not required & & $\begin{array}{l}\text { Management approach } \\
\text { disclosures for each } \\
\text { indicator category }\end{array}$ & & $\begin{array}{l}\text { Management approach } \\
\text { disclosed for each } \\
\text { indicator category }\end{array}$ & \\
\hline & Approach & Report on a & & Report on a minimum of & & Report on each core and & \\
\hline & $\begin{array}{l}\text { Performance } \\
\text { Indicators \& } \\
\text { Sector } \\
\text { Supplement } \\
\text { Performance }\end{array}$ & $\begin{array}{l}\text { performance } \\
\text { indicators (at least } \\
\text { one from each of: } \\
\text { social, economic and } \\
\text { environment). }\end{array}$ & & $\begin{array}{l}\text { Indicators (at least one } \\
\text { from each of: social, } \\
\text { economic and } \\
\text { environment). }\end{array}$ & & $\begin{array}{l}\text { indicator or explain the } \\
\text { reason for its omission. }\end{array}$ & \\
\hline
\end{tabular}

\subsubsection{Categories of the Performance Indicators}

There are six key performance indicator areas of consideration in the GRI's framework; namely, economic, environmental, social (labour practices), social (human rights), social (society) and social (product responsibility).

\subsubsection{Economic (EC) Performance Indicators}

In respect of the economic indicators, it contains areas that include economic performance, market presence and indirect economic impacts. Detailed indicators in these areas are shown in Table 2.

Table 2: Economic Indicators

\begin{tabular}{|l|l|}
\hline Economic Performance & Description \\
\hline EC1 & Direct economic value generated and distributed \\
\hline EC2 & Financial implication, risks and opportunities \\
\hline EC3 & Coverage of the organisation's defined benefit plan obligation \\
\hline EC4 & Significant financial assistance received from government \\
\hline Market Presence & \\
\hline EC5 & Range of ratios of standard entry level wage \\
\hline EC6 & Policy, practices and proportion of spending \\
\hline EC7 & Procedures for local hiring \\
\hline Indirect Economic Impacts & \\
\hline EC8 & Development and impact of infrastructure investments \\
\hline EC9 & Describing direct economic impacts \\
\hline
\end{tabular}

(Adapted from GRI, 2011c) 


\subsubsection{Environmental (EN) Performance Indicators}

With regard to the environmental indicators, they contain areas that include materials, energy, water, biodiversity, emissions, effluents and waste, products and services, compliance, transport and, finally, an overall area. Detailed indicators in these areas are shown in Table 3.

Table 3: Environmental Indicators

\begin{tabular}{|c|c|}
\hline Materials & Description \\
\hline EN1 & Materials used by weight or volume \\
\hline EN2 & Percentage of materials used that are recycled input materials \\
\hline \multicolumn{2}{|r|}{ 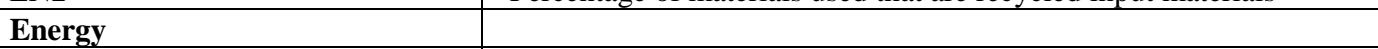 } \\
\hline EN3 & Direct energy consumption by primary energy source \\
\hline EN4 & Indirect energy consumption by primary energy source \\
\hline EN5 & Energy saved \\
\hline EN6 & Initiatives to provide energy-efficient products \\
\hline EN7 & Initiatives to reduce indirect energy consumption \\
\hline \multicolumn{2}{|r|}{ 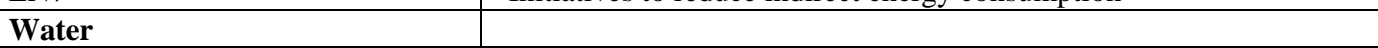 } \\
\hline EN8 & Total water withdrawal by source \\
\hline EN9 & Water source considerably affected by withdrawal of water \\
\hline EN10 & Percentage and total volume of water recycled a \\
\hline \multicolumn{2}{|c|}{ Biodiversity } \\
\hline EN11 & Location and size of land \\
\hline EN12 & Description of considerable impacts of activities \\
\hline EN13 & Habitats protected or restored \\
\hline EN14 & Strategies, current actions and future plans \\
\hline EN15 & Number of IUCN Red List species \\
\hline \multicolumn{2}{|c|}{ Emissions, Effluents \& Waste } \\
\hline EN16 & Total direct and indirect greenhouse gas emissions \\
\hline EN17 & Other relevant indirect greenhouse gas emissions \\
\hline EN18 & Initiatives to lesson greenhouse gas emissions \\
\hline EN19 & Emissions of ozone-depleting substances \\
\hline EN20 & NO,SO and other significant air emissions \\
\hline EN21 & Total water discharge by quality and destination \\
\hline EN22 & Total waste by type and disposal method \\
\hline EN23 & Number and volume of significant spills \\
\hline EN24 & Weight of transported, imported, or treated waste \\
\hline EN25 & Identity, size, protected status, and biodiversity value of water bodies \\
\hline \multicolumn{2}{|c|}{ Products \& Services } \\
\hline EN26 & Initiatives to mitigate environmental impacts \\
\hline EN27 & Percentage of products sold \\
\hline \multicolumn{2}{|l|}{ Compliance } \\
\hline EN28 & Monetary value of significant fines \\
\hline \multicolumn{2}{|l|}{ Transport } \\
\hline EN29 & Significant environmental impacts of transporting products \\
\hline \multicolumn{2}{|r|}{ om } \\
\hline EN30 & Environmental protection expenditures and investments \\
\hline
\end{tabular}

(Adapted from GRI, 2011d)

\subsubsection{Social: Labour Practices and Decent Work (LA) Performance Indicators}

With regard to labour practices and decent work indicators, they contain areas that include employment, management relations, occupational health and safety, training and education, diversity and equal opportunity and, lastly, equal remuneration for men and woman. Detailed indicators in these areas are shown in Table 4. 
Table 4: Labour Practices and Decent Work Indicators

\begin{tabular}{|l|l|}
\hline Employment & Description \\
\hline LA1 & Total workforce \\
\hline LA2 & Number and rate of new employee hires \\
\hline LA15 & Benefits provided to full-time employees \\
\hline Labour/Management Relations & Return to work and retention rates \\
\hline LA4 & Percentage of employees covered by collective bargaining agreements \\
\hline LA5 & Minimum notice periods \\
\hline Occupational Health and Safety & \\
\hline LA6 & Percentage of workforce represented \\
\hline LA7 & Rates of injury, occupational diseases \\
\hline LA8 & Education, training, counselling and prevention \\
\hline LA9 & Health and safety topics covered \\
\hline Training and Education & \\
\hline LA10 & Average hours of training per year \\
\hline LA11 & Programs for skills management \\
\hline LA12 & Percentage of employees receiving reviews \\
\hline Diversity and Equal Opportunity & \\
\hline LA13 & Composition of governance bodies \\
\hline $\begin{array}{l}\text { Equal Remuneration for Woman and } \\
\text { Men }\end{array}$ & \\
\hline LA14 & Ratio of basic salary of men to woman \\
\hline
\end{tabular}

(Adapted from GRI, 2011e)

\subsubsection{Social: Human Rights (HR) Performance Indicators}

With regard to the human right indicators, they contain areas that include investment and procurement practices, non-discrimination, freedom of association, child labour, and prevention of forced and compulsory labour, security practices, indigenous rights, assessment and, finally, remediation. Detailed indicators in these areas are shown in Table 5.

Table 5: Human Rights Indicators

\begin{tabular}{|l|l|}
\hline Investment and Procurement Practices & Description \\
\hline HR1 & Number of significant investment agreements \\
\hline HR3 & Significant suppliers, contractors and business partners \\
\hline Non-discrimination & Total hours of employee training \\
\hline HR4 & Number of incidents of discrimination \\
\hline $\begin{array}{l}\text { Freedom of association and collective } \\
\text { bargaining }\end{array}$ & $\begin{array}{l}\text { Operations and significant suppliers identified in which the right to exercise } \\
\text { freedom of association may be at risk }\end{array}$ \\
\hline HR5 & $\begin{array}{l}\text { Operations and significant suppliers identified as having risk for incidents of child } \\
\text { labour }\end{array}$ \\
\hline Child Labour & $\begin{array}{l}\text { Operations and significant suppliers identified as having risk for incidents of } \\
\text { forced or compulsory labour }\end{array}$ \\
\hline HR6 & \begin{tabular}{l} 
Percentage of security personnel trained \\
\hline Prevention of Forced and Compulsory
\end{tabular} \\
\hline HR7 & \\
\hline Security Practices & \\
\hline HR8 & \\
\hline
\end{tabular}

(Adapted from GRI, 2011f) 


\subsubsection{Social: Society (SO) Performance Indicators}

With regard to society indicators, they contain areas that include local communities, corruption, public policy, anti-competitive behaviour, and compliance. Detailed indicators in these areas are shown in Table 6.

Table 6: Society Indicators

\begin{tabular}{|l|l|}
\hline Local communities & Description \\
\hline SO1 & Percentage of operations with implemented local community engagement \\
\hline SO9 & Operations with considerable potential or negative impacts \\
\hline SO10 & Prevention and mitigation measures \\
\hline Corruption & \\
\hline SO2 & Percentage and total number of business units analysed \\
\hline SO3 & Percentage of employees trained in these policies \\
\hline SO4 & Actions taken in response \\
\hline Public Policy & \\
\hline SO5 & Public policy positions \\
\hline SO6 & Value of financial and in-kind contributions to political parties \\
\hline Anti-competitive Behaviour & \\
\hline SO7 & Number of legal actions \\
\hline Compliance & \\
\hline SO8 & Monetary value of significant fines \\
\hline
\end{tabular}

(Adapted from GRI, 2011g)

\subsubsection{Social: Product Responsibility (PR) Performance Indicators}

With regard to product responsibility indicators, they contain areas that include customer health and safety, product and service labelling, marketing communications, customer privacy and, lastly, compliance. Detailed indicators in these areas are shown in Table 7.

Table 7: Product Responsibility Indicators

\begin{tabular}{|l|l|}
\hline Customer Health and Safety & Description \\
\hline PR1 & Life cycle stages in which relevant impacts of products and services are assessed \\
\hline PR2 & $\begin{array}{l}\text { Number of incidents of non-compliance concerning health and safety impacts of } \\
\text { products and services }\end{array}$ \\
\hline Product and Service Labelling & Type of product and service information required by procedures \\
\hline PR3 & $\begin{array}{l}\text { Number of incidents of non-compliance concerning product and service information } \\
\text { and labelling }\end{array}$ \\
\hline PR4 & Practices related to customer satisfaction \\
\hline PR5 & Programs for adherence to laws, standards and voluntary codes \\
\hline Marketing Communications & Number of incidents of non-compliance concerning marketing communications \\
\hline PR6 & \\
\hline PR7 & Number of substantiated complaints \\
\hline Customer Privacy & \\
\hline PR8 & Monetary value of significant fines \\
\hline Compliance & \\
\hline PR9 & \\
\hline
\end{tabular}

(Adapted from GRI, 2011h)

\section{FUNDAMENTALS OF THE CO-OPERATIVE BUSINESS MODEL}

A co-operative is characterised as an autonomous voluntarily association of persons to meet common economic, social and cultural needs and aspirations through jointly-owned and democratically-controlled enterprises organised and operated on co-operative principles (ICA, 2007, DoED, 2012). The principles of co-operatives involve voluntary and open membership, democratic member control, member economic participation, autonomy and independence, education, training and information, co-operation among co-operatives, and concern for community (ICA, 2007; Kanyane, 2009:1126; DoED, 2012). The co-operative business model is built on key 
values, such as self-help, self-responsibility, democracy, equality, equity, and solidarity. Furthermore, co-operatives' members believe in the ethical values of honesty, openness, social responsibility, and the caring for others (ICA, 2007; Kanyane, 2009:1126; DoED, 2012). The importance of the co-operative sector can be confirmed and demonstrated through the contribution that it has made in past economic developments. Co-operatives have developed along several lines; for example, agricultural co-operatives, consumer co-operatives, credit co-operatives, housing co-operatives, worker co-operatives, and health and social care co-operatives (Birchall, 2004:6-13).

Within the South African context, national government's responsibility for co-operatives falls with the Department of Trade and Industry (DTI) (Nganwa, Lyne \& Ferrer, 2010:40). The Co-operatives Act 14 of 2005 aims to promote the development of sustainable co-operatives in South Africa and their use as a vehicle to develop small enterprises (Nganwa et al., 2010:39). Therefore, this leads to the contribution of economic growth, reduced poverty, employment creation, and assisting in the result of economic transformation and an equitable society (DTI, 2004:5). Nealer and Naudé (2011:115) believe that the multifaceted integrative nature of sustainable development makes it clear that co-operative governance's effective communication and most beneficial collaboration between all actors that are involved are crucial tools for more effective sustainable development (Nealer \& Naudé, 2011:115).

This study is based on a co-operative (Agri-Com), which is a registered low-cost agricultural co-operative, providing selected services such as the finance of input cost, comprehensive insurance on crops, bulk purchase of farming inputs at a discount, and the marketing of members' production to prospective buyers. Although Agri-Com is able to operate nationally, their current markets primarily include grain producers in the Free State and Mpumalanga provinces. Agri-Com has the opportunity to provide a one-stop service in terms of the cultivation of maize, wheat, soy beans, sunflower, sugar beans, and potatoes to selected farmers in these areas. The most important component of the service offering is finance on grain production agreements with approved producers, backed by multi-peril and hail insurance, to cover exposure to insurable natural risks. The service offering is distributed to their own members, but also to the clients of merchant banks and other agri-businesses that have made use of their services in the past 10 years. The fact that approximately $80 \%$ of production inputs are distributed directly from the supplier to the farmer also provides Agri-Com with a competitive advantage, as it will carry no inventory on input commodities. Agri-Com's target market is the top 40 of their existing low-risk grain-producing members who all have a sound financial standing and credit rating. The mission statement testifies that Agri-Com, in co-operation with its stakeholders, will strive toward the financial independence of the farmer.

\section{RESEARCH RESULTS}

The research question enquired as to the extent of the GRI guidelines as a reporting responsibility framework and its feasibility to co-operatives as a business model. In order to report on the following performance indicators, data were used from several meetings held with, and documents and financial statements gathered from, Agri-Com management and personnel. From this data, it was evident that Agri-Com would easily have been able to comply with the Level ' $\mathrm{C}$ ' GRI report. Based on the data, the performance indicators mentioned below were reported on as part of Agri-Com's regular operations.

This section is arranged according to economic, environmental, and social categories where social indicators are further classified by means of Labour, Human rights, Society, and Product responsibility. Agri-Com performed satisfactorily under the Indicator Protocols reported below in the following manner:

\subsection{Economic Performance Indicators}

In reference to Table 2 where there were nine performance indicators identified within the GRI framework, Agri-Com performed as shown in Table 8. 
Table 8: Agri-Com - Economic Performances

\begin{tabular}{|c|c|}
\hline Economic Performance & \\
\hline $\mathrm{EC} 1$ & $\begin{array}{l}\text { Agri-Com Co-operative has a management agreement with Agri-Com Holdings (Pty) Ltd. to } \\
\text { manage the co-operative on behalf of members. A portion of the gross profit of the co-operative } \\
\text { reverts back to Agri-Com Holdings as a management fee and the remainder, after allowing for } \\
\text { expenses, remains in Agri-Com Co-operative to build reserves or to be distributed to members as a } \\
\text { bonus on turnover. Bonuses will, in line with the co-operatives statute, be credited to members' } \\
\text { loan accounts on a 15-year rotation basis. }\end{array}$ \\
\hline $\mathrm{EC} 2$ & $\begin{array}{l}\text { The area in which Agri-Com operates is not a high risk area and risks are furthermore reduced by } \\
\text { cultivating summer and winter crops as well as an animal farming element. The development in } \\
\text { comprehensive crop insurance has the effect that producers are able to pay their input accounts } \\
\text { even in years where adverse weather conditions have an effect on crop yields. }\end{array}$ \\
\hline $\mathrm{EC} 4$ & $\begin{array}{l}\text { Agri-Com's current service offering focuses on securing finance to prospective producers through } \\
\text { a credit facility from The Land and Agri-cultural Development Bank of Southern Africa (Land } \\
\text { Bank) only. }\end{array}$ \\
\hline \multicolumn{2}{|l|}{ Market Presence } \\
\hline $\mathrm{EC} 8$ & $\begin{array}{l}\text { The main service area of Agri-Com is the Eastern Free State. There are a number of poor areas in } \\
\text { the service area of which the most densely populated area is the Phuthaditjhaba area. The } \\
\text { Seothlong School and Maluti FET College are both situated in the town of Phuthaditjhaba. Our } \\
\text { compatriots in the NGF programme indicate that our involvement with the programme is creating } \\
\text { opportunities for people to work, thereby alleviating poverty in the region. }\end{array}$ \\
\hline EC9 & $\begin{array}{l}\text { Development of emerging entrepreneurs - The basis for this plan is to identify and develop } \\
\text { emerging entrepreneurs in the agricultural sector. Seothlong, which educates learners in an } \\
\text { Agricultural curriculum (Grade 8-12), is ideally situated to identify prospects for further } \\
\text { development at an early stage. Agri-Com, with assistance from our suppliers, will support the } \\
\text { theoretical training with hands-on practical training. Together with Maluti FET Department } \\
\text { Agriculture, the intention is to identify young entrepreneurs in the different fields available in } \\
\text { Agriculture and send them for the relevant training to establish entrepreneurs with expertise in } \\
\text { Agriculture. }\end{array}$ \\
\hline
\end{tabular}

In terms of economic performances, Agri-Com is tracking and reporting on five possible indicators; namely, EC1 (Direct economic value generated and distributed), EC2 (Financial implication, risks and opportunities) EC4 (Significant financial assistance received from government), EC8 (Development and impact of infrastructure investments) and, finally, EC9 (Describing direct economic impacts).

\subsection{Environmental Performance Indicators}

In reference to Table 3, the chosen co-operative performed as illustrated in Table 9.

Table 9: Agri-Com - Environmental Performances

\begin{tabular}{|c|c|}
\hline Biodiversity & \\
\hline EN14 & $\begin{array}{l}\text { Agricultural biodiversity, known as agri-biodiversity or the genetic resources for food and } \\
\text { agriculture and a vital sub-set of biodiversity. It is a creation of humankind whose food and } \\
\text { livelihood security depend on the sustained management of those biological resources that are } \\
\text { important for food and agriculture. The most important reason for the existence of Agri-Com is to } \\
\text { contribute to Food Safety and Security in South Africa. Everything that Agri-Com stands for and } \\
\text { does is aimed at making a positive contribution to Food Safety and Security for all the people of } \\
\text { our land. (Contribution to Food Security at National level). }\end{array}$ \\
\hline \multicolumn{2}{|l|}{ Products and Services } \\
\hline EN26 & $\begin{array}{l}\text { The introduction of innovative ideas in Agriculture, with the establishment of a sugar bean trading } \\
\text { market for their members. The sugar bean programme consists of the full spectrum of activities } \\
\text { from financing the cultivation of beans through cleaning and packaging to marketing of the beans. } \\
\text { As far as we know, Agri-Com is the only Co-operative participating in the full spectrum of the } \\
\text { sugar bean trade. The sugar and soy beans that they finance put nitrogen back into the ground and } \\
\text { are used to fertilise the ground for the planting of future crops. }\end{array}$ \\
\hline
\end{tabular}


In terms of environmental performances, Agri-Com is tracking and reporting on only two possible indicators; namely, EN14 (Strategies, current actions, and future plans) and EN26 (Initiatives to mitigate environmental impacts).

\subsection{Social (Labour Practices) Performance Indicators}

In reference to Table 4, the chosen co-operative performed as shown in Table 10.

Table 10: Agri-Com - Social (Labour Practices) Performances

\begin{tabular}{|l|l|}
\hline Training and Education & $\begin{array}{l}\text { Agri-Com's personnel policy indicates that opportunities as far as training is concerned are made } \\
\text { available to all permanently appointed personnel. Their training policy stipulates that personnel are } \\
\text { trained firstly through in-house practical training and financial assistance is also available to } \\
\text { personnel for appropriate specialised training. }\end{array}$ \\
\hline
\end{tabular}

In terms of social (labour practices) performances, Agri-Com is tracking and reporting on only the LA11 (Programs for skills management) indicator.

\subsection{Social (Human Rights) Performance Indicators}

In reference to Table 5, the chosen co-operative performed as shown in Table 11.

Table 11: Agri-Com - Social (Human Rights) Performances

\begin{tabular}{|l|l|}
\hline Non-discrimination & \\
\hline HR4 & $\begin{array}{l}\text { The Co-operative business form lends itself for participation on a broad basis to all races, without } \\
\text { the potential interference by outside political groupings. Agri-Com Co-operative Ltd. is an } \\
\text { agricultural co-operative and its membership is open to all bona fide farmers, irrespective of race, } \\
\text { colour or creed. In fact, Agri-Com has black female members, which makes it a non-racist and non- } \\
\text { sexist organisation. All members have equal voting powers. }\end{array}$ \\
\hline
\end{tabular}

In terms of social (labour practices) performances, Agri-Com is tracking and reporting on only the HR4 (Number of incidents of discrimination) indicator.

\subsection{Social (Society) Performance Indicators}

In reference to Table 6, Agri-Com performed as shown in Table 12.

Table 12: Agri-Com - Social (Society) Performances

\begin{tabular}{|l|l|}
\hline Local Communities & \\
\hline SO9 & $\begin{array}{l}\text { Agri-Com recognises its social responsibility as a whole and regularly contributes to deserving } \\
\text { projects. The Co-operative's involvement with the Seothlong Agricultural School project in Qwa } \\
\text { Qwa and the Qwa Qwa emerging farmers illustrates the social involvement. }\end{array}$ \\
\hline
\end{tabular}

In terms of social (labour practices) performances, Agri-Com is tracking and reporting on only the SO9 (Operations with considerable potential or negative impacts) indicator.

When considering that there are in excess of 80 possible performance indicators, Agri-Com currently tracked and reported on 10 of such indicators. Furthermore, considering that of five of these indicators fall within the economic category, it is obvious that, in this instance, the more conventional social aspects of social responsibility reporting, as per the GRI framework, receives less attention that it could. 


\section{CONCLUSIONS}

\subsection{Concluding Discussions}

The purpose of this study was to emphasise the importance of the co-operative business model in the modern, socially responsible, business environment and the contribution it can make to the community at large. The GRI's Sustainability Reporting Framework, which is the most widely used framework, was analysed, evaluated and applied to a chosen co-operative's operational activities and reports. The primary research question was the extent to which the GRI guidelines would be feasible or applicable to co-operatives. The previously mentioned objective could only be answered by the following secondary objectives, which were to analyse the GRI framework in order to identify key components thereof, the evaluation of the co-operative business model and principles within the context of the above, and, finally, the interpretation and evaluation of the GRI's report template in terms of the objectives of the co-operative business model by means of a case study.

The research indicated that the co-operative performed particularly well under the economic performance indicators, where the direct economic value generated and distributed, the financial implications due to climate change, significant financial assistance received from government, development and impact of infrastructure investments and finally indirect economic impacts were reported on. Under the environmental performance indicators, it was ironically more difficult to report on, but plans for managing impacts on biodiversity and initiatives to mitigate environmental impacts of products and services were reported on. The social performance indicators displayed good performance under the training and education aspect, where programmes for skills management were reported on. Non-discrimination under human rights performance indicators reported on the total number of incidents and, finally, under the society performance indicators, local community's aspect was the most prominent because of the co-operative's contribution to the community.

The GRI's Sustainability Reporting Guidelines represent the accountability to both internal and external stakeholders for organisational performance toward the aim of sustainable development. From the evaluation of the co-operative business model, it is clear that it has the same goal in mind, which is sustainable development.

Finally, the chosen agricultural co-operative performed considerably well under these guidelines, even though it is not a requirement for them to do so. From now on forward, the co-operative can apply itself to improve to a more supplementary application level. It is therefore recommended that further environmental performance indicators should be investigated and more attention must be paid to this matter.

\subsection{Limitations and Shortcomings}

The result of this study is limited by the fact that only one co-operative in the Free State Province was used; therefore, it cannot just be assumed that all co-operatives within a global context will perform in the same manner. Furthermore, the study is also restricted by the fact that this chosen study is based on an agricultural co-operative, thereby limiting the application of the results of this study to co-operatives in other forms.

The contribution of the study is the fact that important potential shortcomings in the reporting model of the co-operative have been identified. As a co-operative, it should focus more on the environmental performance indicators for the reason that even though it is an agricultural co-operative, according to the GRI's framework, the chosen co-operative can work on additional performance indicators in this area. Simultaneously, the application levels will follow an incremental approach to reporting and will expand over time.

\subsection{Future Research}

As far as future research opportunities in an evaluation of the co-operative business model within the context of the GRI are concerned, different types of co-operative models can also be targeted for research. This, in turn, may also give rise to sector supplements that can be tailored for the co-operative sector with its unique characteristics. The reason for this is that co-operatives confront rare issues that may not typically be covered in the original Guidelines. 


\section{ACKNOWLEDGEMENT}

The authors are grateful to the NRF for financial support provided for this study. Any opinion, findings, and conclusions or recommendations are those of the authors and therefore the NRF does not accept any liability in regard thereto.

\section{AUTHOR INFORMATION}

Marné du Toit is currently a full-time master's degree student at the North-West University in South Africa's Potchefstroom campus. This article is based on the research conducted for her Masters' degree in Management Accountancy.

Professor Pieter W Buys is currently the Research Program Leader at the North-West University (South Africa) and holds two PhDs (Accountancy and Management Accountancy), two Masters Degrees (MComm and MBA), and he is also a US Certified Management Accountant (CMA). He has worked in the ERP and business consulting industry in Canada, the USA and South Africa for more than 15 years. He has published more than 40 articles in peer-reviewed and professional publications. His current research revolves around corporate social responsibility and resilience. E-mail: Pieter.Buys@nwu.ac.za (Corresponding author)

\section{REFERENCES}

1. Acquier, A. \& Aggeri F. (2007). The Development of a CSR industry: Legitimacy and feasibility as the two pillars of the institutionalization process. In Den Hond, F., De Bakker, F.G.A. \& Neergaard, P., ed. Managing corporate social responsibility in action: talking, doing and measuring. Farnham: Ashgate. p. 149-165.

2. Birchall, J. (2004). Cooperatives and the millennium development goals. Geneva: International Labour Organisation.

3. Blowfield, M. \& Murray, A. (2008). Corporate responsibility: A critical introduction. New York: Oxford University Press.

4. De Bakker, F.G.A., Ohlsson, C., Den Hond, F., Tengblad, S. \& Turcotte, M.B. (2007). Tracing evolution of corporate discourse on corporate social responsibility: A longitudinal, lexicological study. In Den Hond, F., De Bakker, F.G.A. \& Neergaard, P., ed. Managing corporate social responsibility in action: talking, doing and measuring. Farnham: Ashgate. p. 53-73.

5. Demirag, I. (2005). Introduction. Responsibility, accountability and governance: The presumed connections with the state, the market and the civil society and an overview. In Demirag, I., ed. Corporate social responsibility, accountability and governance: Global perspectives. Sheffield: Greenleaf Publishing.

6. DoED see KwaZulu-Natal. Department of Economic Development.

7. Dilling, P.F.A. (2010)." Sustainability reporting in a global context: what are the characteristics of corporations that provide high quality sustainability reports: An empirical analysis." International Business \& Economics Research Journal, 9(1):19-30.

8. $\quad$ DTI see South Africa. Department of Trade and Industry.

9. GRI (Global Reporting Initiative) (2011a). "Sustainability Reporting Guidelines." https://www.globalreporting.org/reporting/latest-guidelines/g3-1-guidelines/Pages/default.aspx Date of access: 25 Feb. 2012.

10. GRI (Global Reporting Initiative) (2011b). "GRI Application Levels." https://www.globalreporting.org/reporting/latest-guidelines/g3-1-guidelines/Pages/default.aspx Date of access: 25 Feb. 2012.

11. GRI (Global Reporting Initiative) (2011c). "GRI Indicator Protocol set (Economic)." https://www.globalreporting.org/reporting/latest-guidelines/g3-1-guidelines/Pages/default.aspx Date of access: 25 Feb. 2012.

12. GRI (Global Reporting Initiative) (2011d). "GRI Indicator Protocol set (Environment)." https://www.globalreporting.org/reporting/latest-guidelines/g3-1-guidelines/Pages/default.aspx Date of access: 25 Feb. 2012. 
13. GRI (Global Reporting Initiative) (2011e). “GRI Indicator Protocol set (Labor Practices and Decent Work).” https://www.globalreporting.org/reporting/latest-guidelines/g3-1-guidelines/Pages/default.aspx Date of access: 25 Feb. 2012.

14. GRI (Global Reporting Initiative) (2011f). "GRI Indicator Protocol set (Human Rights).” https://www.globalreporting.org/reporting/latest-guidelines/g3-1-guidelines/Pages/default.aspx Date of access: 25 Feb. 2012.

15. GRI (Global Reporting Initiative) (2011g). "GRI Indicator Protocol set (Society)." https://www.globalreporting.org/reporting/latest-guidelines/g3-1-guidelines/Pages/default.aspx Date of access: 25 Feb. 2012.

16. GRI (Global Reporting Initiative) (2011h). "GRI Indicator Protocol set (Product Responsibility)." https://www.globalreporting.org/reporting/latest-guidelines/g3-1-guidelines/Pages/default.aspx Date of access: 25 Feb. 2012.

17. ICA (International Cooperative Alliance). (2007). http://www.ica.coop Date of access: 26 Feb. 2012.

18. ICA (International Cooperative Alliance). (2012. http://www.ica.coop Date of access: 25 July 2012.

19. Institute of Directors (IoD). (2009). "King committee on governance: draft code of governance principles for South Africa - 2009.” www.iodsa.co.za Date of access: 28 Feb 2012.

20. IoD see Institute of Directors

21. Jones III, A, \& Jonas, G.A. (2011). "Corporate social responsibility reporting: the growing need for input from the accounting profession.” The CPA Journal: 65-71, Feb.

22. Jooste, L. (2010). "Accounting ethics: an empirical investigation of managing short term earnings." African Journal of Business Ethics, 13(1):98.

23. Kanyane, M.H. (2009). "Co-operatives as part of social security mainstream for poverty alleviation in selected municipalities.” Journal of Public Administration, 44(4):1124-1137, December.

24. KwaZulu-Natal. Department of Economic Development. (2012). "Co-operatives." http://kznded.gov.za/Default.aspx?tabid=255 Date of access: 11 Jan. 2012.

25. Levy, D.L. \& Brown, H.S. (2011). The Global Reporting Initiative: Collaboration and conflict in the development of non-financial reporting. In Jain, S.C. \& Kedia, B.L., ed. Enhancing global competitiveness through sustainable environmental stewardship. Cheltenham: Edward Elgar. p. 129.

26. Munkelien, E.B., Goyer, P.R. \& Fratczak, I. (2005). CSR in the Scandinavian countries: A review of voluntary versus regulated. In Demirag, I., ed. Corporate social responsibility, accountability and governance. Sheffield: Greenleaf. p. 182-197.

27. Nealer, E.J. \& Naudé, M. (2011). "Integrated co-operative governance in the context of sustainable development." The Journal for Transdisciplinary Research in Southern Africa, 7(1):105-118.

28. Nganwa, P., Lyne, M. \& Ferrer, S. (2010). "What will South Africa's new cooperatives act do for small producers? An analysis of three case studies in KwaZulu-Natal." Agrekon, 49(1):39-40, March.

29. Nikolaou, I.E., Evangelinos, K.I. \& Allan, S. (2012). “A reverse logistics social responsibility evaluation framework based on the triple bottom line approach." Journal of Cleaner Production (In press).

30. Rossouw, D. (2009). Managing ethics. In Rossouw, D., Du Plessis, C., Prinsloo, F., Prozesky, M., eds. Ethics for accountants and auditors. Southern Africa: Oxford University Press. p. 165-177.

31. South Africa. Department of Trade and Industry. (2004). A co-operative Development Policy for South Africa.

32. Verschoor, C.C. (2011). "Ethics: should sustainability reporting be integrated?” Strategic Finance: 12-14, Dec.

33. White, G.B., Cleveland, M.J. \& White, M.J. (2008). "Perceptions of environmental sustainability." Journal of Business and Economic Research, 6(4):31-42. 


\section{NOTES}

